\title{
FISH COMMUNITY STRUCTURE IN TEMPORARY LOWLAND FLOODED GRASSLANDS
}

\author{
A. CARPENTIER (1), J.-M. PAILLISSON (1), E. FEUNTEUN (2), L. MARION (1)
}

(1) Université de Rennes 1, UMR Écobio 6553, avenue du Général Leclerc, 35042 Rennes Cedex, France. Tél. : (33) 02232361 47, Fax : (33) 0223235138. Courriel : alexandre.carpentier@univ-rennes1.fr

(2) Université de La Rochelle, LBEM, avenue M. Crépeau, 17042 La Rochelle Cedex.

Reçu le 8 août 2002

Accepté le 24 janvier 2005

Received August 8, 2002

Accepted January 24, 2005

\begin{abstract}
In the context of a clear-cutting experiment of sedge areas on seasonally flooded grasslands, we described the fish community structure and the relationships between its spatial organisation and some environmental variables in early spring in 2000. A confinement gradient related to an increase in macrophyte density and determined by the nearest distance from permanent waters seemed to be a key factor in structuring the fish community in the flooded grasslands. Along this gradient, Cyprinids (essentially $0+$ ) dominated near permanent water bodies (95\% in abundance) but were substituted further by more tolerant species (Anguilla anguilla and Lepomis gibbosus) and mainly Ameiurus melas (age $>1,40 \%$ in abundance). Although most species (10/13) present in the main permanent channels have been found in flooded grasslands, the efficiency of these grasslands as fish habitat was low compared to other similar sites from literature. We concluded on the importance of a confinement gradient and the water regime, isolating grasslands during summer and responsible of the scarce presence of fish.
\end{abstract}

Key words: fish assemblages, temporarily flooded grasslands, colonization, confinement gradient, multivariate analyses, electrofishing.

\section{STRUCTURE DE LA COMMUNAUTÉ PISCICOLE DANS DES PRAIRIES INONDABLES DE PLAINE}

\section{RÉSUMÉ}

Dans le cadre d'une campagne de gyrobroyage de cariçaies au sein de prairies temporairement inondées, nous décrivons la structure de la communauté piscicole et les relations entre son organisation spatiale et certaines variables environnementales au début du printemps de l'année 2000. Un gradient de fermeture du milieu lié à une augmentation de la densité de macrophytes et déterminé par la distance la plus courte aux zones aquatiques permanentes semble être prépondérant quant à la structuration de la communauté piscicole dans les prairies inondables. Les Cyprinidés (essentiellement des $0+$ ) sont majoritaires aux entrées des prairies (95\% en abondance) puis remplacés par des espèces plus tolérantes (Anguilla anguilla et Lepomis gibbosus), et plus particulièrement par Ameiurus melas ( $40 \%$ en abondance, âge $>1$ ) à mesure que le gradient de fermeture s'intensifie. Bien que la plupart des espèces (10/13) présentes dans 
les milieux permanents aient été recensées dans les prairies inondables, l'utilisation de ces prairies comme habitat par les poissons est restée faible comparativement à ce qui est décrit dans d'autres sites semblables. Nous concluons sur l'importance d'un gradient de confinement et du régime hydraulique, responsables de l'isolement des prairies pendant l'été et de la pauvreté du peuplement piscicole.

Mots-clés : peuplement piscicole, prairies inondables, colonisation, gradient de confinement, analyses multivariées, pêche électrique.

\section{INTRODUCTION}

Temporary aquatic habitats such as tidal marshes, backwaters or floodplains are known to be of importance as nursery areas and/or spawning grounds for many fish species both in marine areas (TALBOT and ABLE, 1984; LEFEUVRE et al., 1999; LAFFAILLE et al., 2000) and in fresh waters (e.g. COPP and PENAZ, 1988; POIZAT and CRIVELLI, 1997). These ecological functions are rather well documented for marginal habitats and tidal freshwater marshes or salt marshes (WEINSTEIN, 1979; ROZAS and ODUM, 1987; MC IVOR and ODUM, 1988; SCHLOSSER, 1995), but only a few papers concern seasonally flooded marshes (SNODGRASS et al., 1996; POIZAT and CRIVELLI, 1997; BABER et al., 2002).

Seasonally flooded habitats are often characterised by good feeding and growth conditions for most fish species (NECKLES et al., 1990). Furthermore, the shallowness of these areas is not suitable for most large piscivorous fishes and provides some protection for coarse fish (MC IVOR and ODUM, 1988; SCHLOSSER, 1995). This advantage is balanced by the occurrence of specialised fish-eating birds such as Ardeidae, which exert a significant predation (KUSHLAN, 1976a), especially in confined areas (FEUNTEUN and MARION, 1994; MARION et al., 2000). Moreover, during the dry season, as the water level decreases, high mortality rates may occur for fish trapped in isolated water bodies (KUSHLAN, 1976a, b; CAPONE and KUSHLAN, 1991). Therefore, the degree of connection between temporary and permanent habitats determines the accessibility, the functions and the efficiency of these habitats for fish (SCHLOSSER, 1982; SNODGRASS et al., 1996; POIZAT and CRIVELLI, 1997).

In the present paper, we first report data on the fish community structure in seasonally flooded grasslands in the Loire estuary (Grande Brière, France) in early spring in 2000. Restoration programs have been recently conducted here to counteract the landscape closure by tall helophytes, caused by the abandonment of traditional human activities since the second part of the $20^{\text {th }}$ century (see study area section). Clear-cutting experiments of sedge areas were conducted to favour the return of cattle grazing. This management measure provided an opportunity to describe the fish community in these formerly sedge beds turned into grasslands. We also tested the effect of several environmental factors on the spatial organisation of the fish assemblage. These preliminary results on the functions (from the size class study) and the efficiency (according to the distance gradient) of these new grasslands for the fish community were discussed and compared to previous fish data collected in some permanent waterbodies of the Grande Brière marshes.

\section{STUDY AREA}

The Grande Brière Mottière is a large wetland (7 $000 \mathrm{ha})$ originally belonging to the Loire estuary floodplain (France $47^{\circ} 22^{\prime} \mathrm{N}, 02^{\circ} 11^{\prime} \mathrm{W}$, Figure 1). In the past, the tidal influence was limited by a natural rocky sill, resulting in a wide oligohaline to freshwater area. Since the last transgression (8 $000 \mathrm{BP}$ ), peat lands developed there and large reed or sedge beds progressively colonized the whole surface. Grande Brière marshes were for a long time exploited for peat and were used as a natural navigation passage between Guérande 
saltpans and the Loire River for the salt trade. These activities created a permanent water body composed of a dense network of 2 to $15 \mathrm{~m}$ wide ditches $(400 \mathrm{~km})$ and ponds created by peat extraction for fuel. Another important activity was cattle and horse farming: when the water level receded at spring time, more than 3000 cattle and horses used to be stocked there to graze the reed beds, which were progressively replaced by Glyceria fluitans and Agrostis stolonifera grasslands. A set of sluices was built at the end of the $19^{\text {th }}$ century at the outlet of the marsh in order to control the water levels and to prevent marine incursions into the marsh. Recently, in the second part of $20^{\text {th }}$ century, peat extraction and cattle grazing were progressively abandoned, leading to a decrease of surfaces of grassland and permanent water (decrease from $80 \%$ in 1940 to $15 \%$ in 1980 of the total area for grasslands, from 700 ha in 1948 to 270 ha in 1980 of permanent water areas). This change in human activities has played a great role in the decrease of the biodiversity (BERNARD and ROLLAND, 1990; EYBERT et al., 1998). In order to mitigate this trend, several restoration programs have been initiated in the past twenty years.

The study took place in three sedge bed areas (G1, G2 and G3 covering respectively 15, 20 and $40 \mathrm{ha}$ ), which were experimentally rotavated in 1997 (Figure 1). For facility, these areas will be named grasslands in the text although it is not totally true from a botanical point of view. They are surrounded by sedge and reed beds and are connected to permanent waters (close ditches) by few openings dug in banks formed by settling of materials stemming from clearance operations. Whereas banks isolate well grasslands from adjacent ditches, the openings which are about $20 \mathrm{~cm}$ higher than the mean level of
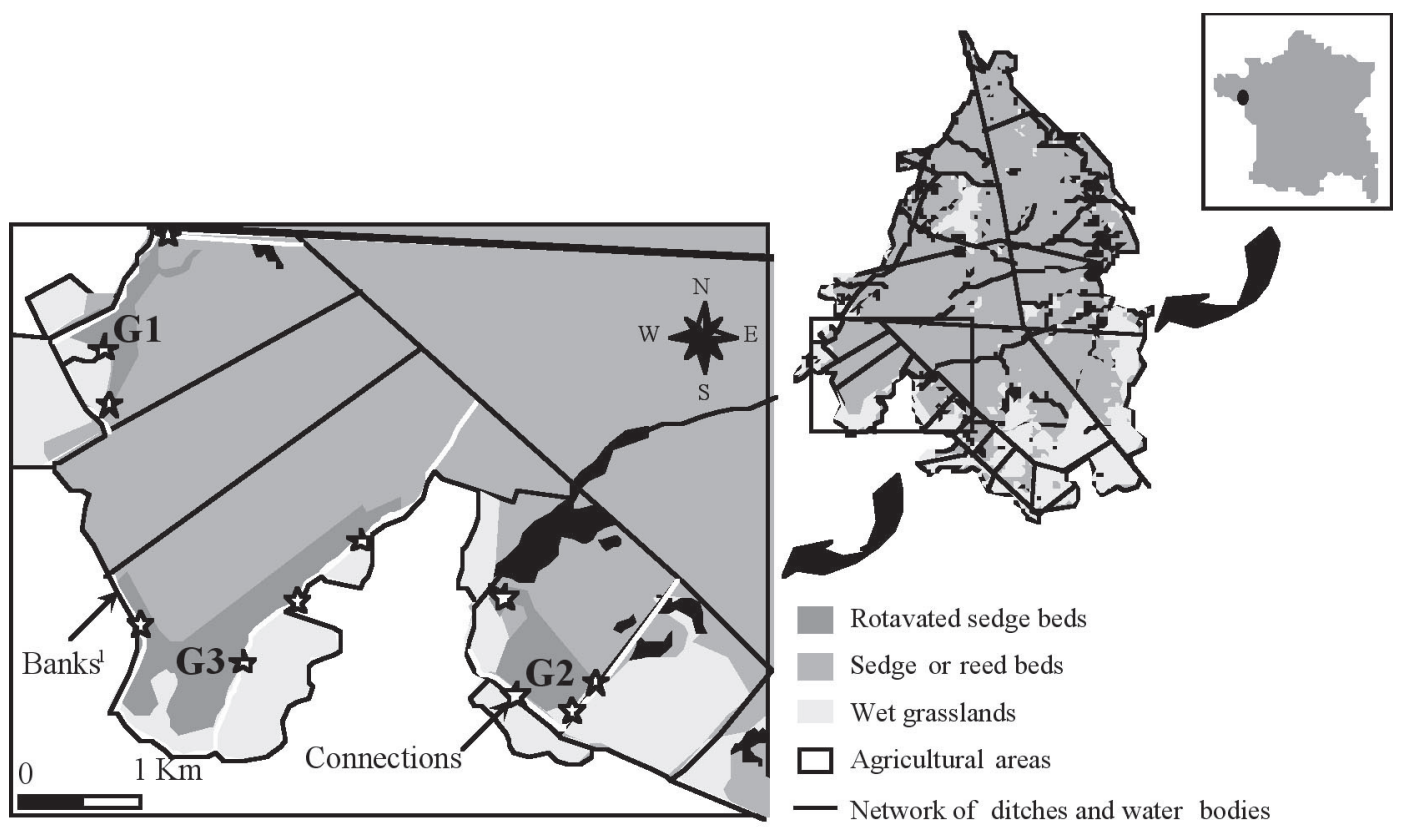

Figure 1

Description of the Grande-Brière marsh including the studied flooded grasslands connected to permanent waters (close ditches) by few openings (stars) dug in banks (white lines) formed by settling of materials stemming from clearance operations.

\section{Figure 1}

Description des marais de Grand-Brière incluant les prairies inondables étudiées connectées au milieu permanent (douves voisines) par quelques dépressions (étoiles) creusées dans les bourrelets de curage (lignes blanches). 


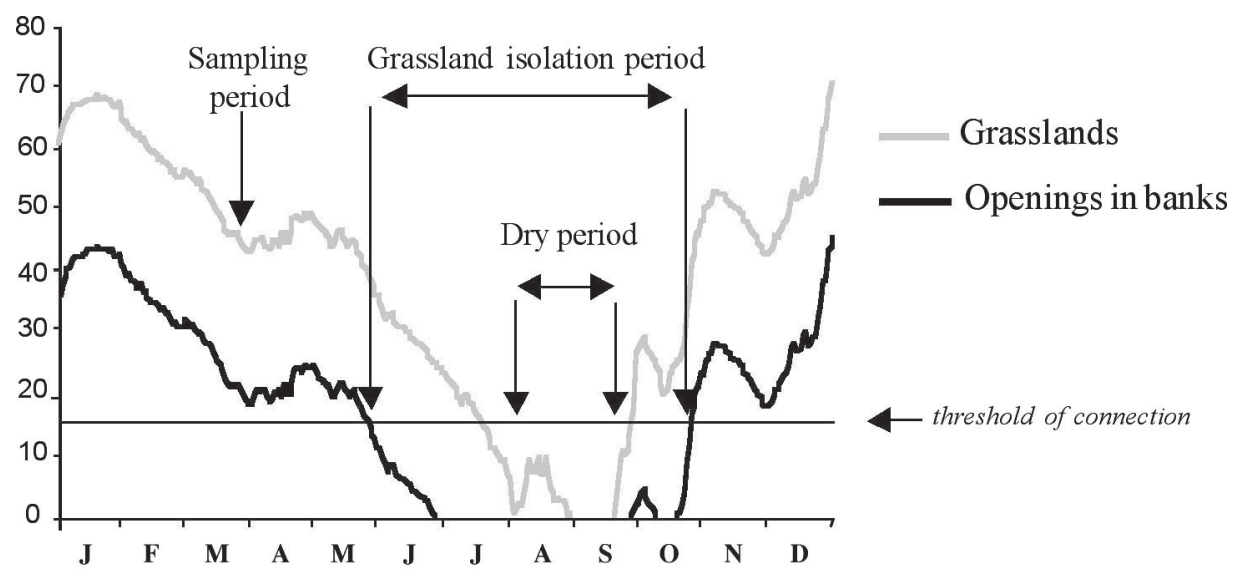

Figure 2

Water level fluctuations on grasslands.

Figure 2

Fluctuations du niveau d'eau sur les prairies.

the grasslands allow fish exchange between flooded grasslands and ditches according to the water regime. Generally, like in 2000 , the highest water level occurred in winter (from 50 to $70 \mathrm{~cm}$ ) and then progressively fell until the grasslands became dry in summer (Figure 2). The access to and the suitability of temporary habitats are low from mid-May when a threshold of $15 \mathrm{~cm}$ water over connections is recorded preventing fish exchanges with permanent water due to ground unevenness. In early spring, a dense uniform aquatic vegetation cover occurs in grasslands, composed of submerged macrophytes and filamentous algae. A few deeper artificial peat extraction pools occur but they are rapidly isolated from the ditch network during spring.

\section{MATERIAL AND METHODS}

\section{Fish sampling}

Fish sampling was conducted in early spring (21-24 March) when most fish species are active (water warming), before the grassland isolation period. Fishing was conducted in the morning (8:00-13:00) using an electro-fishing apparatus (EFKO F.E.G. 8000 ) providing a fully rectified, triphase $\mathrm{AC}$ of 300 to $600 \mathrm{~V}$ and until $30 \mathrm{~A}$. The point abundance sampling (PAS) was used (NELVA et al., 1979), this sampling strategy being chosen because it is well adapted to shallow waters and is effective for all species and most life stages (ROUSSEAU et al., 1985; NELVA, 1988; HUTAGALUNG et al., 1997). A $30 \mathrm{~cm}$ diameter anode was used as a good compromise for fish sampling since most 0+ fish were over $40 \mathrm{~mm}$ length at this period, knowing that a small diameter anode (10$15 \mathrm{~cm}$ ) is efficient for fish larvae (> $10 \mathrm{~mm}$ ) (COPP and PENAZ, 1988; GARNER, 1997) and larger anodes (40 cm diameter) are generally used for large fish (e.g. PERSAT and COPP, 1989). A total of 184 stations (43, 57 and 84 stations respectively in G1 (15 ha), G2 (20 ha) and G3 (40 ha)) were carried out randomly in the grasslands in order to cover the whole accessible area and notably to relate fish data with a distance gradient between ditches and flooded grasslands (see the next section). There were no fundamental differences in the sampling effort according to grasslands (ratio between station numbers and accessible area). Station numbers are related to values recommended by COPP and GARNER (1995) and GARNER (1997) for between-site comparisons in species composition. The sampling method was applied by throwing the anode from a non-motorized boat to a distance of 
5 to $10 \mathrm{~m}$ before collecting shocked fish to reduce disturbance, each spot sample being furthermore separated by a minimum of $50 \mathrm{~m}$. Fish were identified to species, measured to the nearest millimetre and immediately returned to water. Abramis bjoerkna and Abramis brama were grouped and always considered together since juveniles were not reliably identifiable in the field.

\section{Environmental variables}

For each station, we measured three environmental variables: water depth $(\mathrm{cm})$, aquatic vegetation cover (mainly Ceratophyllum spp., Myriophyllum spp. and Enteromorpha spp.) defined in four classes (scattered vegetation (0-25\% coverage), medium (25-50\%), dense $(50-75 \%)$ and fully coverage $(75-100 \%))$ and distance to the nearest connection with a permanently flooded ditch defined in four classes $(0-10 \mathrm{~m}, 11-30 \mathrm{~m}, 31-50 \mathrm{~m}$ and $>50 \mathrm{~m}$ ). The substrate nature was not used since it was relatively homogeneous (peat) and was composed of plant debris and a thin mud layer. The water temperature was very stable $\left(14 \pm 1^{\circ} \mathrm{C}\right)$ and was not used in the analysis.

\section{Data analysis}

Measures of species diversity were calculated for the fish communities of each grassland including specific richness, Shannon diversity index and Equitability (Ecolostat software, GUILLORY, 1999). Differences in relative abundance of fish species in the community of the three grasslands were tested using Spearman rank correlation (Systat 9, SPSS, 1998). The same statistical procedure was used to test changes in relative abundance of the fish species according to the distance gradient (four classes) when data of the three replicates (G1, G2, G3) were combined.

Ordination analysis with the direct gradient technique of the canonical correspondence analyses (CCA) was performed to investigate the association of the fish community to the set of environmental variables and to identify habitat variables contributing to spatial segregation of fish species. This method chooses the ordination axes on the basis of species and environnemental data and displays locations for sites (stations) and species (weighted averages) in ecological space assuming a Gaussian-type response to environmental gradients (arrows) (TER BRAAK, 1986, 1996). The CCA was tested using a Monte Carlo permutation test ( $n=500$ random permutations). The multivariate procedure was performed with CANOCO (version 4.51, TER BRAAK and SMILAUER, 2003).

\section{RÉSULTS}

A total of 709 fish belonging to 10 species and 7 families were collected (Table 1). Species richness ranged from 7 (G3) to 8 (G1/G2), the difference between the three grasslands resulting in the capture of one individual of Gambusia affinis in G1 and 2 individuals of Perca fluviatilis in G2. Shannon diversity index seemed higher in G2 (2.40) than in G1 (2.01) and G3 (1.76). Similar results were found for Equitability: 0.79 in G2 and 0.63 and 0.67 respectively in G3 and G1. However there were no fundamental changes in the significance of relative abundance of fish species according to replicates (Spearman rank correlations, $0.899<\mathrm{rs}<0.986, \mathrm{p}=0.05$ ). Globally, when data of the three grasslands were combined, fish were caught in a total of 71 stations $(38.6 \%$ of total stations sampled). Number of species varied from 1 to 4 species according to stations and 40 of them had only one species. The four Cyprinid species caught in flooded grasslands largely dominated the community $(87.8 \%$ in abundance) despite their relatively low occurrences (5.4-12.0\%, Table I). Conversely, the occurrence of Ameiurus melas was the highest (17.4\%) despite low number of individuals (6.6\% in abundance). Esox lucius, Anguilla anguilla and Lepomis gibbosus were scarce. Cyprinids were essentially represented by 0+ fish (44-124 mm), Ameiurus melas and Esox lucius mainly 


\section{Table I}

List of species caught in seasonally flooded grasslands from Brière in March 2000. Common and scientific name, code species, number and occurrence are given for each species. Data of the three grasslands ( $n=184$ stations) were combined (see results section).

\section{Tableau I}

Liste des espèces capturées dans les prairies inondables de Brière en mars 2000. Le nom scientifique, le nom commun, le code, l'abondance et l'occurrence sont donnés pour chaque espèce. Les données des trois prairies ( $n=184$ stations) ont été regroupées (voir la partie résultats).

\begin{tabular}{|c|c|c|c|c|c|}
\hline Family & Scientific name & $\begin{array}{l}\text { Common } \\
\text { name }\end{array}$ & $\begin{array}{c}\text { Code } \\
\text { species }\end{array}$ & Number & $\begin{array}{c}\% \\
\text { Occurrence }\end{array}$ \\
\hline \multirow{2}{*}{$\begin{array}{l}\text { Anguillidae } \\
\text { Ictaluridae }\end{array}$} & Anguilla anguilla & Eel & ANAN & 14 & 6.5 \\
\hline & Ameiurus melas & Catfish & AMME & 46 & 17.4 \\
\hline \multirow{3}{*}{ Cyprinidae } & Rutilus rutilus & Roach & RURU & 174 & 9.2 \\
\hline & $\begin{array}{l}\text { Scardinius } \\
\text { erythrophtalmus }\end{array}$ & Rudd & SCER & 189 & 12.0 \\
\hline & $\begin{array}{c}\text { Abramis brama } \\
\text { Abramis } \\
\text { bjoerkna }\end{array}$ & Breams & $\begin{array}{c}\text { ABBR \& } \\
\text { ABBJ }\end{array}$ & 260 & 5.4 \\
\hline Esocidae & Esox lucius & Pike & ESLU & 6 & 3.3 \\
\hline Poeciliidae & \multirow{3}{*}{$\begin{array}{c}\text { Gambusia affinis } \\
\text { Lepomis } \\
\text { gibbosus } \\
\text { Perca fluviatilis }\end{array}$} & Mosquito fish & & 1 & 0.5 \\
\hline Centrarchidae & & Pumpkinseed & LEGI & 17 & 8.2 \\
\hline Percidae & & Perch & & 2 & 0.5 \\
\hline
\end{tabular}

by age $>1$ fish $(87 \%$ of individuals $>110 \mathrm{~mm}$ for Ameiurus melas and $385-505 \mathrm{~mm}$ for Esox lucius), and Anguilla anguilla and Lepomis gibbosus by all age classes (149-689 mm and $26-128 \mathrm{~mm}$ respectively).

The species-environment correlations were 0.60 and 0.41 respectively for the first two axes of the CCA. The first two eigenvalues displayed $15 \%$ of the total inertia (total variance in species abundance data), and $96 \%$ of the variance in the weighted average of the species with the environmental variables. The Monte Carlo test for the first and all axes were significant $(p<0.001)$. Figure 3 is not very faithful in displaying the observed abundances, but highly faithful in displaying the fitted abundance values, weighted averages of fish species. It can be deducted from the figure, that fish species arranged mainly along a distance gradient from permanent habitats associated with an increasing vegetation cover (correlation coefficients with the CCA axis $1=0.88$ and 0.48 respectively). Cyprinid species (Rutilus rutilus, Scardinius erythrophtalmus and Abramis brama/Abramis bjoerkna) were recorded mainly in stations close to permanent habitats poorly vegetated and Anguilla anguilla, Ameiurus melas and Esox lucius were caught in stations further from permanent habitats with dense vegetation. The second axis reflecting a water depth gradient (correlation coefficient with the CCA axis $2=0.97$ ) was less informative since it only distinguished Lepomis gibbosus from the other fish species.

Consequently, as seen in Figure 4, the relative abundances of fish species near permanent water bodies were significantly different from those recorded further away in the grasslands. Only two significant correlations were found for $0-10 / 11-30 \mathrm{~m}$ and 11 $30 / 31-50$ m classes. The proportion of Cyprinids decreased from $95.1 \%(0-10 \mathrm{~m})$ to $24.4 \%$ 


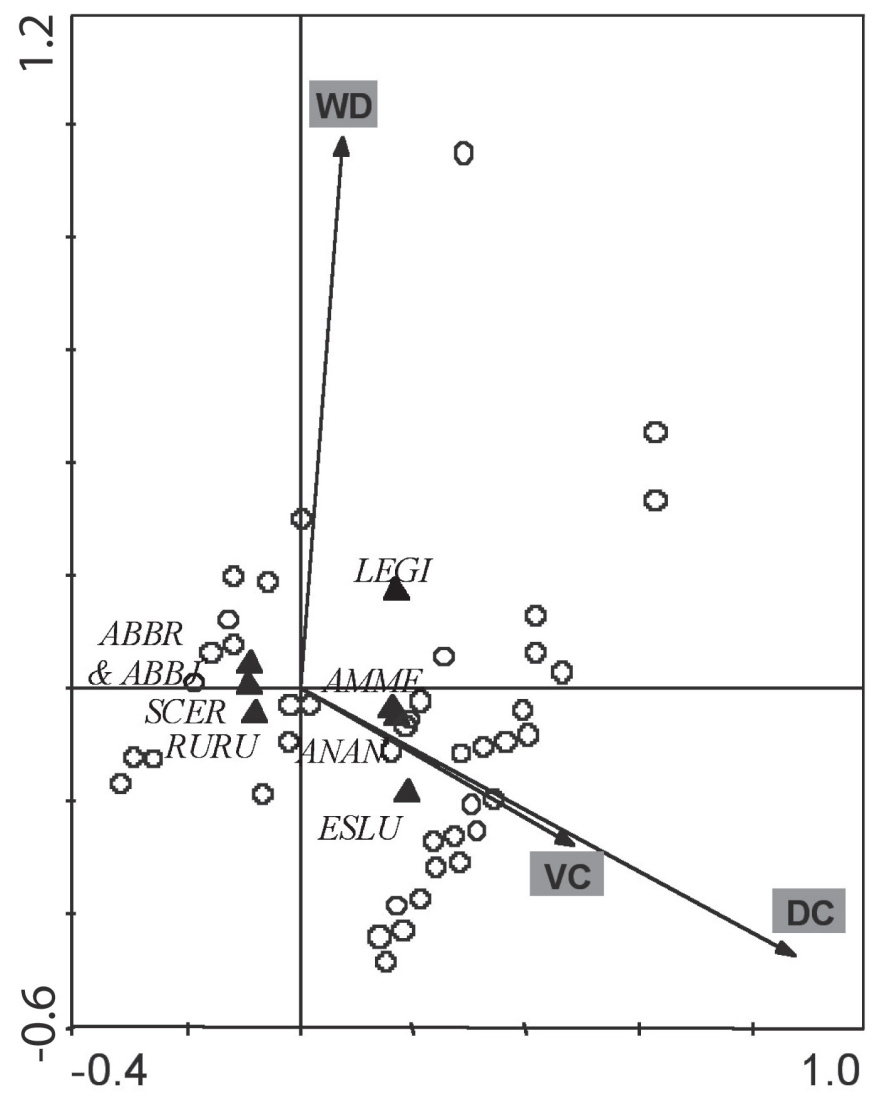

Figure 3

Results of the Canonical Correspondence Analysis on the contingency table (stations-species abundance) showing station scores (open circles) and species scores (closed triangles) along environmental gradients (arrows). Full species names are given in Table I. WD: water depth, VC: vegetation cover and DC: distance to the nearest connection.

\section{Figure 3}

Résultats de l'Analyse Canonique des Correspondances sur le tableau de contingence (abondance des espèces par stations) montrant la position des stations (cercles vides) et espèces (triangles noirs) le long de gradients définis par les variables environnementales (flèches). Les noms complets des espèces sont reportés dans le tableau I. WD : hauteur d'eau, VC : couverture végétale et DC : distance au canal le plus proche.

(> $50 \mathrm{~m}$ ) in abundance whereas mainly Ameiurus melas increased from 2.6 to $40.0 \%$. At the same time, the number of fish caught strongly decreased from $14.0 \pm 10.5$ fish per station in the $0-10 \mathrm{~m}$ zone to $0.4 \pm 0.1$ fish per station in the $>50 \mathrm{~m}$ zone (Figure 5). Moreover, fish age $>2$ which represented a tiny proportion near permanent water bodies (1.4\%) increased progressively with distance and were the most abundant at the $>50 \mathrm{~m}$ zone $(37.8 \%)$.

\section{DISCUSSION}

The flooded grasslands can be considered as unpredictable habitats for fish species as a result of the seasonal character of flooding and limited possibilities of fish movement via connections to permanent water bodies according to the water regime. 

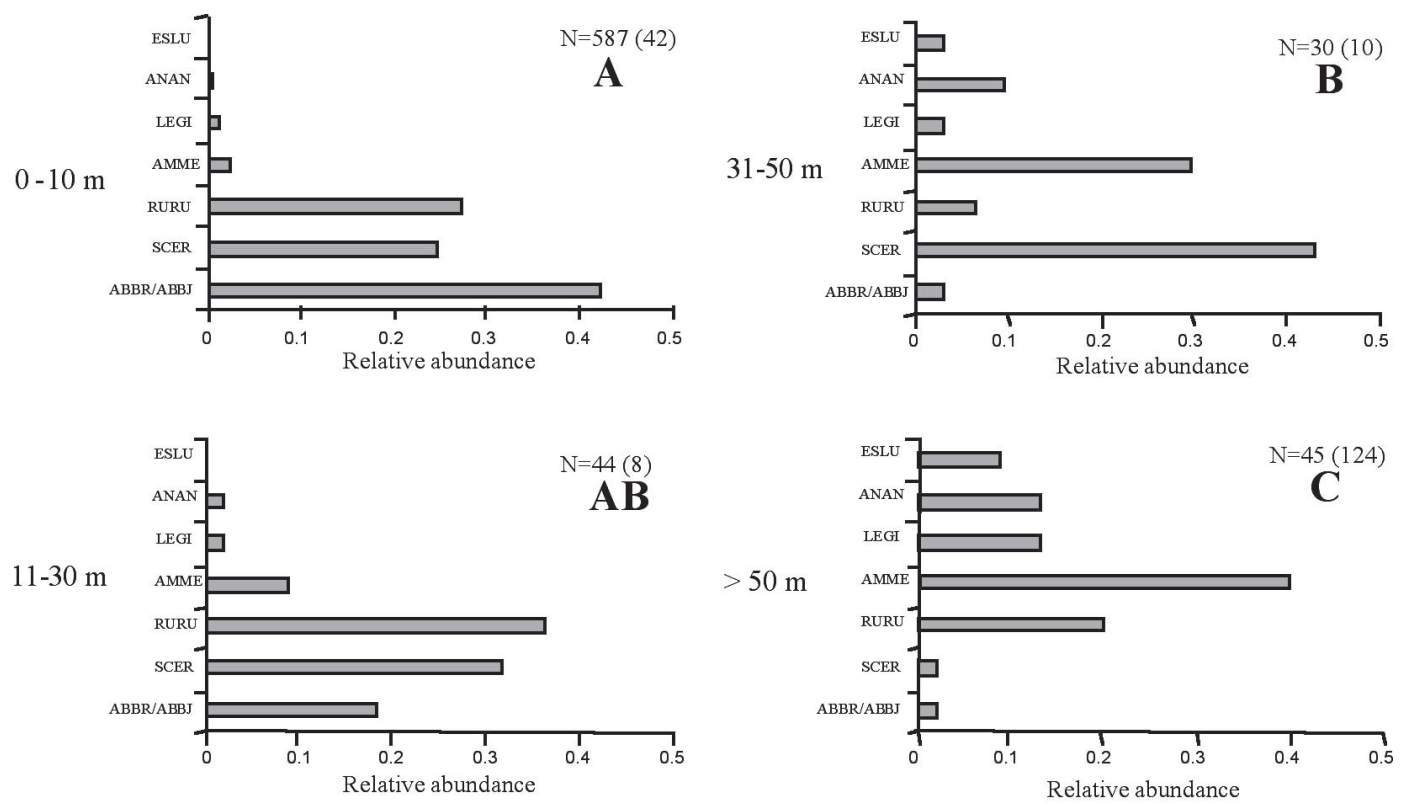

Figure 4

Abundance of fish species (expressed in \%) according to the distance gradient between permanent waters and temporarily flooded grasslands. A letter code was attributed to each distance class and must be read as following: distance classes with the same letter are not significantly different at $p<0.05$ from pair wise comparison in Spearman Rank tests. The number of fish and stations sampled (in brackets) was given for each distance class.

\section{Figure 4}

Abondance des espèces de poissons (exprimées en \%) en fonction du gradient de distance entre les eaux permanentes et les prairies inondables. A chaque classe de distance est attribué un code lettre qui s'interprète comme suit : les classes de distance ayant une lettre identique ne sont pas significativement différentes à $p<0,05$ selon la comparaison de rang deux à deux de Spearman. Le nombre de poissons et de stations échantillonnées (entre parenthèses) est donné pour chaque classe de distance.

However, the comparison of the fish community composition recorded in 2000 within temporarily flooded grasslands with those of previous studies conducted in several permanent water bodies of the same wetland (EYBERT et al., 1998) shows that 10 of a total of 13 fish species occur in temporary flooded grasslands. Cyprinus carpio, Tinca tinca and Zander lucioperca were not recorded in the present study. Moreover, relative abundance of common species differed significantly between both habitats (Spearman rank correlation, $r s=1.05, p>0.05$ ). The role of these temporary habitats as spawning, refuge and feeding grounds for fish species and the degree of colonization may explain the differences recorded with permanent areas.

\section{The functional role of temporarily flooded grasslands}

The temporary character of flooded grasslands limits the time of colonization by fish and prevents most of them from completing their entire life cycle (spawning, growing and feeding stages). Because of habitat constraints due to the water regime and the biology of each fish species, a limited number of age classes was noted for most of species, 


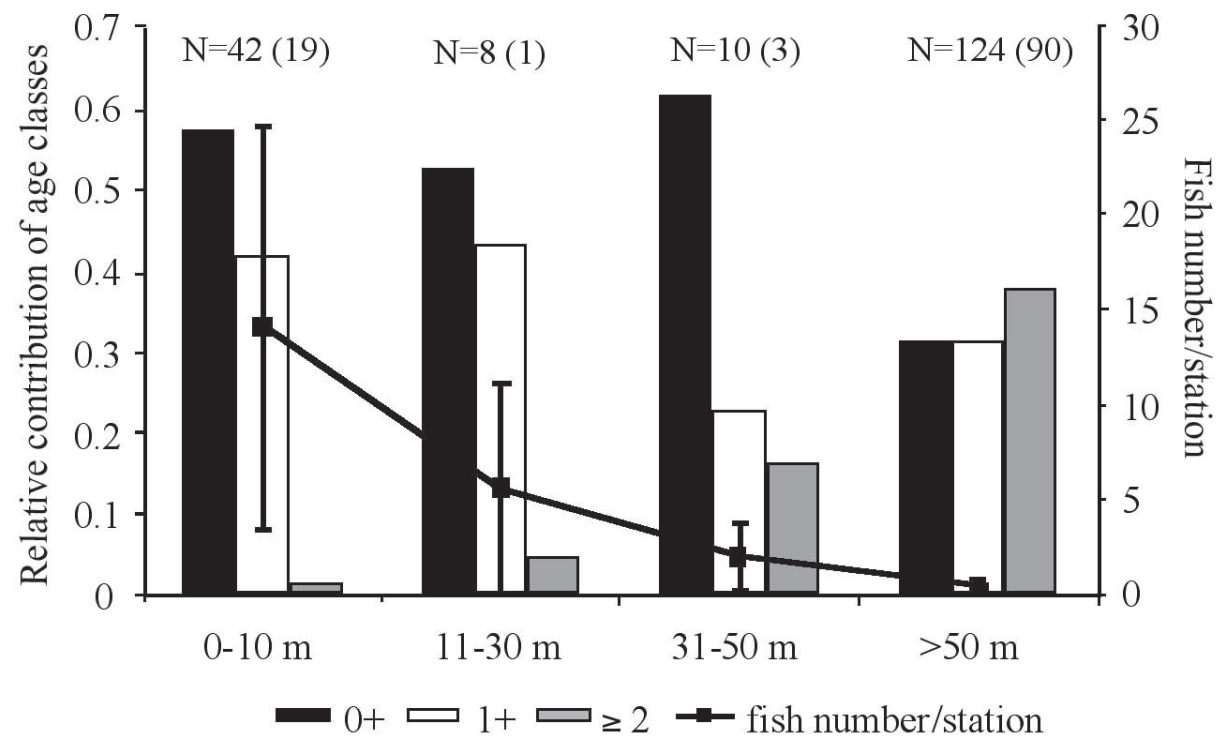

Figure 5

Abundance of each age class of fish (expressed as \%, histograms) and abundance (mean with $95 \%$ confidence interval) of fish per station (solid line with squares) according to the distance gradient between permanent waters and temporary flooded grasslands. The number of stations was given for each distance class with the number of stations without fish indicated in brackets.

\section{Figure 5}

Abondance des différentes classes d'âge de poissons (histogrammes exprimés en $\%$ ) et abondance globale par station (courbe moyenne avec un intervalle de confiance à $95 \%$ ) en fonction du gradient de distance entre les eaux permanentes et les prairies inondables. Le nombre de stations est donné pour chaque classe de distance avec entre parenthèses celles pour lesquelles aucun poisson n'a été capturé.

except for Ameiurus melas and mainly Lepomis gibbosus. These latter non-indigenous species and nest guarder spawners are more tolerant and not dependent on water depth, but greatly prefer a dense vegetation cover (THIERO YATABARY, 1981; GRENOUILLET, PONT and OLIVIER, 2000). Ameiurus melas age $>1$, which is dominant in the present study, is known to inhabit a wide range of ecosystems, from deep oxbows (COPP, 1989; GOZLAN et al., 1998; BERREBI-DIT-THOMAS, 1999) to shallow isolated ponds (THIERO YATABARY, 1981; DECLERCK et al., 2002). The high colonization capacity of exogenous species (BABER et al., 2002) may explain their adaptative success and importance in fish communities. In our case, only non-indigenous species (Ameiurus melas and Lepomis gibbosus) colonize the major parts of the flooded grasslands. Cyprinids, which are supposed to use these flooded grasslands as refuge and feeding areas, were mainly present near connections with permanent areas. SNODGRASS et al. (1996) found similar results in isolated wetlands, stating that in severely perturbed habitats, fish assemblage structure depends more on colonization rates than on biotic interactions or size and complexity of habitats. Nevertheless, as shown by HOHAUSOVA, COPP and JANKOVSKY (2003), floodplain fish species are able to change their location relative to the main channel between night and day. As nighttime were not investigated in this study, it is possible that fish change their location in temporary flooded-grasslands. In the present study, Anguilla anguilla and Esox lucius were present at very low abundance and these grasslands might 
not play their role of spawning ground for early spawners like Esox lucius (CASSELMAN and LEWIS, 1996; LE LOUARN and FEUNTEUN, 2001) and of nursery/ feeding area for opportunistic species like Anguilla anguilla (FEUNTEUN et al., 1999, 2000). This latter species has the capacity to move over land between water bodies when feeding or habitat quality become unsuitable (BAISEZ, 2001).

\section{Confinement gradient between permanent and temporary habitats and efficiency of flooded grasslands as fish habitat}

First mentions on the biological functions of flooded areas were made by ANTIPA (1928) who hypothesized that fish production in floodplain rivers is directly proportional to the intensity and duration of inundation. Afterwards, BOTNARIUC (1967) and KUSHLAN (1976b) showed the impact of the seasonal fluctuation in water level on fish community composition but also on other aquatic organisms. Our study described different patterns and intensities of colonization of temporary flooded grasslands by fish probably depending on a gradient of distance from connection to permanent waters. Most young fish stay in the 0-50 $\mathrm{m}$ zone from the permanent areas and are progressively replaced by fish $>$ age 1 becoming dominant in the $>50 \mathrm{~m}$ zone. At the same time, dense vegetation was relatively constant far away from connections and seemed to prevent colonization by fish and especially young fish. In this context, the water level characterised by small changes within the flooded grasslands represented only a secondary factor in the spatial distribution of fish species contrarily to results found in some other related studies in different systems: tidal marshes (ROZAS and ODUM, 1988), stream pools (CAPONE and KUSHLAN, 1991), backwaters (GRENOUILLET, PONT and OLIVIER, 2000), artificial submersible dykes (NICOLAS and PONT, 1995) but also in comparable seasonally flooded marshes (POIZAT and CRIVELLI, 1997). Consequently, changes in the fish community described here occurred along a confinement gradient defined by the distance from permanent waters: young Cyprinidae are progressively replaced by mainly age $>1$ Esocidae, Ictaluridae, Anguillidae and Centrarchidae in waters farthest away from connections with permanent waters. In the same way, MARIANI (2001) reported that the patterns of spatial fish distribution in coastal lagoons reflected a confinement gradient in the ecosystems studied. In the present study, the high degree of isolation recorded in the flooded grasslands $(62 \%$ of stations were not colonized by any fish) rapidly limited the efficiency of these habitats for the fish community of permanent waters.

Fish population densities are often low in such habitats indicating either a strong dispersal or aggregative behaviour of the fish community (CRIVELLI, 1981; PONT et al., 1991). The present adverse conditions thus did not favour an optimum use of these seasonally flooded habitats and led to a strong dispersal of fish populations. Moreover the water regime did not provide connections for a long period, since the flooded grasslands were completely isolated from permanent habitats from mid-May. Only most tolerant species such as Ameiurus melas, Anguilla anguilla and Lepomis gibbosus would be able to survive in the isolated pools. In this way, nursery functions for Cyprinidae would only be fulfilled in a reduced part near connections with permanent waters and spawning functions only for most tolerant species with strong risk of trapping as grasslands dried out.

These findings are relevant to "connectivity" concepts (AMOROS and ROUX, 1988; AMOROS and BORNETTE, 1999), which have been mainly studied in French rivers (e.g. NICOLAS and PONT, 1995), and in the Danube delta and tributaries (e.g. TOCKNER et al., 1999; HOHAUSOVA, 2000; HOHAUSOVA, COPP and JANKOVSKY, 2003). Connectivity rather than surface area of floodplains explained the presence of fish and depended on a natural water regime determining successional pattern and habitat heterogeneity (TOCKNER, et al., 1999). Moreover, connectivity governs fish biodiversity and functional roles of flooded areas for different fish species (NICOLAS and PONT, 1995; HOHAUSOVA, 2000; HOHAUSOVA, COPP and JANKOVSKY, 2003). 


\section{CONCLUSION}

These preliminary results on the structure of the fish community in temporary flooded grasslands of the Grande Brière permit us to plan some environmental engineering management options of these habitats to take into account and improve their roles for fish species. We propose to conduct complementary studies on the roles of connectivity and water level management on fish and their habitats.

\section{ACKNOWLEDGEMENTS}

The authors wish to express their gratitude to J.-P. Damien et J.-P. Halgand for their help in the fieldwork and an anonymous referee for comments on an earlier draft of the paper. Dr. R. Britton made linguistic improvements of the manuscript. This work was supported by the Parc Naturel Régional de Brière, the University of Rennes 1 and the CNRS (UMR 6553 Écobio).

\section{REFERENCES}

AMOROS C., ROUX A.L., 1988. Interaction between water bodies within the floodplains of large rivers: function and development of connectivity. Pp 125-130. In: K.F. SCHREIBER (ed.) Connectivity in Landscape Ecology. Proceedings of the $2^{\text {nd }}$ International Seminar of the "International Association for Landscape Ecology". Münster.

AMOROS C., BORNETTE G., 1999. Antagonistic and cumulative effects of connectivity: a predictive model based on aquatic vegetation in riverine wetlands. Arch. Hydrobiol. Suppl., 115/3, 311-327.

ANTIPA G., 1928. Die biologischen Grundlegen und der Mechanismus der Fischproduktion in den Gewässern den unteren Donau. Bull. Sect. Sci. Acad. Roumaine, 11, 1-20.

BABER M.J., CHILDERS D.L., BABBITT K.J., ANDERSON D.H., 2002. Controls on fish distribution and abundance in temporary wetlands. Can. J. Fish. Aquat. Sci., 59, 1441-1450.

BAISEZ A., 2001. Optimisation des suivis des indices d'abondances et des structures de taille de l'anguille européenne (Anguilla anguilla, L.) dans un marais endigué de la côte atlantique: relation espèce habitat. Thèse de doctorat, Université de Toulouse III.

BERNARD J.-Y., ROLLAND R., 1990. Restoration of the "Grande-Brière Mottière" marsh overhauling's project of the stretches of water. Bull. Ecol., 21, 15-19.

BERREBI-DIT-THOMAS R., 1999. Le recrutement des communautés piscicoles dans les annexes hydrauliques de la Plaine de la Bassée (Seine). Thèse de doctorat, Université de Paris VI.

BOTNARIUC N., 1967. Some characteristics features of the floodplain ecosystems of the Danube. Hydrobiologia, 8, 39-50.

CAPONE T.A., KUSHLAN J.A., 1991. Fish community structure in dry-season stream pools. Ecology, 72, 983-992.

CASSELMAN J.-M., LEWIS C.A., 1996. Habitat requirement of northern pike (Esox lucius). Can. J. Fish. Aquat. Sci., 53 (suppl. 1), 161-174.

COPP G.H., 1989. The habitat diversity and fish reproductive function of floodplain ecosystems. Environ. Biol. Fish., 26, 1-26. 
COPP G.H., PENAZ M., 1988. Ecology of fish spawning and nursery zones in the flood plain, using a new sampling approach. Hydrobiologia, 169, 209-224.

COPP G.H., GARNER P., 1995. Evaluating microhabitat use of fish larvae and juveniles with Point Abundance Sampling. Folia Zool., 44, 145-158.

CRIVELLI A., 1981. Les peuplements de poissons de la Camargue. Rev. Ecol. (Terre Vie), $35,617-671$.

DECLERCK S., LOUETTE G., DE BIE T., DE MEESTER L., 2002. Patterns of diet overlap between populations of non-indigenous and native fishes in shallow ponds. J. Fish Biol., 61, 1182-1197.

EYBERT M.C., BERNARD J.-Y., CONSTANT P., FEUNTEUN E., 1998. Réhabilitation des prairies inondables dans les marais briérons : évolution de la flore, des poissons et des oiseaux. Gib. Faune Sauv., 15 (3), 999-1016.

FEUNTEUN E., MARION L., 1994. Assessment of Grey Heron predation on fish communities: the case of the largest European colony. Hydrobiologia, 279-280, 327-344.

FEUNTEUN E., RIGAUD C., ELIE P., LEFEUVRE J.-C., 1999. Les peuplements piscicoles des marais littoraux de l'ouest de la France : un patrimoine à gérer? Bull. Fr. Pêche Piscic., 352, 63-79.

FEUNTEUN E., ACOU A., LAFFAILLE P., LEGAULT A., 2000. The European Eel (Anguilla anguilla, L.): prediction of spawner escapement from continental population parameters. Can. J. Fish. Aquat. Sci., 57, 1627-1635.

GOZLAN R. MASTRORILLO S., DAUBA F., TOURENQ J.N., COPP G.H., 1998. Multiscale analysis of habitat use by $0+$ fishes during late summer in the river Garonne (France). Aquat. Sci., 59, 1-19.

GARNER P., 1997. Sample sizes for length and density estimation of $0+$ fish when using point sampling by electrofishing. J. Fish. Biol., 50, 95-106.

GRENOUILLET G., PONT D., OLIVIER J.-M., 2000. Habitat occupancy patterns of juvenile fishes in a large lowland river: interactions with macrophytes. Arch. Hydrobiol., 149, 307-326.

GUILLORY V., 1999. Ecolostat, version B, Université de Rennes, France.

HOHAUSOVA E., 2000. Exchange rate and small-scale movements of fish between a river and its backwater. Arch. Hydrobiol., 147, 485-504.

HOHAUSOVA E., COPP G.H., JANKOVSKY P., 2003. Movement of fish between a river and its backwater: diel activity and relation to environmental gradients. Ecol. Freshw. Fish., 12, 107-117.

HUTAGALUNG R.A., LIM P., BELAUD A., LAGARRIGUE T., 1997. Effets globaux d'une agglomération sur la typologie ichtyenne d'un fleuve : cas de la Garonne à Toulouse (France). Ann. Limnol., 33, 263-279.

KUSHLAN J.A., 1976a. Wading bird predation in a seasonally fluctuating pond. Auk, 93, 464-476.

KUSHLAN J.A., 1976b. Environmental stability and fish community diversity. Ecology, 57, 821-825.

LAFFAILLE P., FEUNTEUN E., LEFEUVRE J.-C., 2000. Composition of fish communities in a European macrotidal salt marsh (the Mont Saint-Michel Bay, France). Estuar. Coast. Shelf S., 51, 429-438. 
LEFEUVRE J.-C., LAFFAILLE P., FEUNTEUN E., 1999. Do fish communities function as biotic vectors of organic matter between salt marshes and marine coastal waters? Aquat. Ecol., 33, 293-299.

LE LOUARN H., FEUNTEUN E., 2001. Le Brochet. Pp. 226-229. In: P. KEITH, J. ALLARDI (Coord.). Atlas des poissons d'eau douce de France. Patrimoines Naturels. Muséum National d'Histoire Naturelle, Paris.

MARIANI S., 2001. Can spatial distribution of ichthyofauna describe marine influence on coastal lagoons? A central Mediterranean case study. Estuar. Coast. Shelf S., 52, 261-267.

MARION L., FEUNTEUN E., CARPENTIER A., RIGAUD C., 2000. Feeding strategies modification of Grey Herons (Ardea cinerea L.) in response to major decline of preyed fish community's biomass. Arch. Hydrobiol., Verh. Internat. Ver. Limnol., 27, 1-3.

MC IVOR C., ODUM W.E., 1988. Food, predation risk, and microhabitat selection in a marsh fish assemblage. Ecology, 69, 1341-1351.

NELVA A., 1988. Profil écologique du Hotu, Chondrostoma nasus (Ostéichtyen, Cyprinidé) dans le Haut-Rhône français : structure d'habitat ponctuel et stationnel. Acta Oecologica, 9, 275-296.

NELVA A., PERSAT H., CHESSEL D., 1979. Une nouvelle méthode d'étude des peuplements ichthyologiques dans les grands cours d'eau par échantillonnage ponctuelle d'abondance. CR Acad. Sci., 289, 1295-1298.

NECKLES H.A., MURKIN H.R., COOPER J.H., 1990. Influences of seasonal flooding on macroinvertebrate abundance in wetland habitats. Freshwater Biol., 23, 311-322.

NICOLAS Y., PONT D., 1995. Importance d'annexes latérales artificielles pour le recrutement en juvéniles de poissons dans un fleuve aménagé, le Bas-Rhône. Bull. Fr. Pêche et Piscic., 337/338/339, 249-257.

PERSAT H., COPP G.H., 1989. Electrofishing and Point Abundance Sampling for the ichthyology of large rivers. pp. 203-215. In: I. COWX (ed.) Developments in Electrofishing, Fishing News Books, Blackwell Scientific Publishing, Oxford.

POIZAT G., CRIVELLI A., 1997. Use of seasonally flooded marshes by fish in a Mediterranean wetland: timing and demographic consequences. J. Fish Biol., 51, 106-119.

PONT D., CRIVELLI A.J., GUILLOT F., 1991. The impact of three-spined sticklebacks on the zooplankton of a previously fish-free pool. Freshwater Biol., 26, 149-163.

ROUSSEAU B., NELVA A., PERSAT H., CHESSEL D. 1985. Constitution d'une base de données ichtyologiques par l'échantillonnage ponctuel d'abondance : application aux peuplements du Haut-Rhône français. Cybium, 9, 157-173.

ROZAS L.P., ODUM W.E., 1987. Use of tidal freshwater marshes by fishes and macrofaunal crustaceans along a marsh stream-order gradient. Estuaries, 10, 36-43.

ROZAS L.P., ODUM W.E., 1988. Occupation of submerged aquatic vegetation by fishes: testing the role of food and refuge. Oecologia, 77, 101-106.

SCHLOSSER I.J., 1982. Fish community structure and function along two habitat gradients in a headwater stream. Ecol. Monogr., 52, 395-414.

SCHLOSSER I.J., 1995. Dispersal, boundary processes, and trophic-level interactions in streams adjacent to beaver ponds. Ecology, 76, 908-925. 
SNODGRASS J.W, BRYAN A. L. Jr., LIDE R.F., SMITH G.M., 1996. Factors affecting the occurrence and structure of fish assemblages in isolated wetlands of the upper coastal plain, U.S.A. Can. J. Fish. Aquat. Sci., 53, 443-454.

SPSS Inc., 1998. SYSTAT Version 9 for Windows: statistics. Chicago.

TALBOT C.W., ABLE K.W., 1984. Composition and distribution of larval fishes in New Jersey High Marshes. Estuaries, 7, 434-443.

TER BRAAK C.J.F., 1986. Canonical correspondence analysis: a new eigenvector technique for multivariate direct gradient analysis. Ecology, 67, 1167-1179.

TER BRAAK C.J.F., 1996. Unimodal models to relate species to environment. DLOAgricultural Mathematics Group, Wageningen.

TER BRAAK C.J.F., SMILAUER P., 2003. CANOCO for Windows 4.51. Biometris. Plant Research International, Wageningen.

THIERO YATABARY N.K., 1981. Étude de quelques aspects du régime alimentaire et de la croissance de deux poissons Silurodei : Ictalurus melas et Synodontis schall. Thèse de doctorat Université de Toulouse.

TOCKNER K., SCHIEMER F., BAUMGARTNER C., KUM G., WEIGAND E., ZWEIMULLER I., WARD J.V., 1999. The Danube restoration project: species diversity patterns across connectivity gradients in the floodplain system. Regul. Rivers: Res. Mgmt., $15,245-258$.

WEINSTEIN M.P., 1979. Shallow marsh habitats as primary nurseries for fishes and shellfish, Cape Fear river, North Carolina. Fish. Bull., 77, 339-357. 